\title{
EFFECT OF FEEDING LOW-PROTEIN, L-LYSINE AND DL-METHIONINE-SUPPLEMENTED DIETS ON THE GROWTH PERFORMANCE AND CARCASS CHARACTERISTICS OF BROILERS
}

\author{
Gaafar, $K^{1}$., S. I. Fathalla ${ }^{2}$, and M. A. Helal ${ }^{3}$ \\ ${ }^{1}$ Department of Nutrition and Clinical Nutrition; Faculty of \\ Vet. Med. Menoufia University \\ ${ }^{2}$ Department of Physiology; Faculty of Vet. Med. Menoufia University \\ ${ }^{3}$ Department of Husbandry and Animal Wealth Development; Faculty of \\ Vet. Med. Menoufia University
}

\begin{abstract}
Two hundred day-old unsexed broiler (Cobb 500) chicks were randomly distributed to four groups. The first (control) group was fed on starter $(22 \% \mathrm{CP}, 3100 \mathrm{Kcal} / \mathrm{kg} \mathrm{ME}, 1.10 \%$ Lysine, and $0.48 \%$ Methionine) and finisher (20\% CP, $3200 \mathrm{Kcal} / \mathrm{Kg} \mathrm{ME,} \mathrm{0.90 \%} \mathrm{Lysine,}$ and $0.35 \%$ Methionine) diets. The other three groups were fed on three starter and finisher isocaloric isonitrogenou diets with $2 \%$ lower protein content than the diets of control group with addition of graded levels of L-lysine HCl and DL-methionine to give 120\%, 140\%, and $160 \%$ of the NRC (2000), At the end of starting period, the increased Lysine and Methionine content of the low-protein starter's rations didn't affect body weight and gain but increased the feed consumption and decreased the feed conversion ratio of the birds. At the end of finishing period, body weight, body gain, feed intake, and breast meat yield increased significantly with the increasing of synthetic amino acids in the diets, while the best feed conversion ratio was obtained with $120 \%$ amino acids level. Plasma uric acid level increased with
\end{abstract}


feeding broiler on low protein diets and with increasing of synthetic amino acids supplementation to the diets. Plasma Creatinine increased in the birds fed on low-protein diet supplemented with the highest synthetic amino acids level (160\%). Plasma Calcium wasn't affected by the treatment while phosphorus increased in the birds fed on low-protein, DL-Methionine and L-lysine supplemented diets compared with the control group, which might be as indicator for enhanced growth of these groups. It could be concluded that the minimum levels of protein $(20 \%$ and $18 \%$ for starting and finishing periods, respectively) in the broiler's diets supplemented with $120 \%$ of $N R C$ requirements for Lysine and Methionine requirements ensure an optimum body weights, body gains, and feed conversion ratios with reduced plasma level of Uric acid but were inadequate to produce the highest breast meat yield.

Kay words: Low-protein; Lysine; Methionine; Broiler.

\section{INTRODUCTION}

It is generally believed that the provision of amino acids either free or usually in the form of protein, accounts for high proportion of the cost of practical diets for poultry. The ideal diets should exactly satisfy the requirements of the target species for amino acids, to achieve the maximum economic return. It is more economically efficient to use lysine and DL-methionine as pure supplements in producing mixed feed for broiler production rather than as components of intact protein. All amino acids supplied by the dietary protein become available to the animal during digestion and metabolism. Excess dietary protein increases heat production and water consumption which increase water content of the litter (Alleman and Leclercq, 1997). 
An attempt to reduce the protein level of the diet would help to decrease the nitrogen excretion, diet cost, allow for use of alternate feedstuffs, and improve tolerance to heat stress. Reducing crude protein with amino acids supplementation of the diet support good growth and feed consumption of broilers (Yamazaki et al., 1998, Aletor et al., 2000) and may decrease the marketing age. Methionine and Lysine are considered to be the first and second limiting essential amino acids in chicks fed on corn-soybean meal diets. An important aspect of the protein and methionine interrelationship is the ability of both to act as lipotropic agents (Hueghebaert et al., 1994). Addition of methionine and/or lysine above the recommended requirement of broilers improves their performance in terms of body weight gain and food conversion efficiency (Ohta and Shbashi, 1995, Rezaei et al., 2004, Schutle et al., 1997, Simon et al., 1995). The objective of this study was to evaluate the effect of reducing dietary protein with methionine and lysine supplementation on the growth performance and carcass characteristics of broilers.

\section{MATERIALS AND METHODS}

Two hundred day-old unsexed broiler (Cobb 500) chicks were randomly distributed to control and three experimental groups, 50 chicks in each. Birds were reared till the marketing weight (five weeks old) through two experimental periods, starting (0-2 weeks) and finishing (25 weeks) periods.

Two diets for the control group were formulated with nutrients proportions of dry matter according to NRC (2000). They were used as starter $(22 \% \mathrm{CP}, 3100 \mathrm{Kcal} / \mathrm{kg} \mathrm{ME}, 1.10 \%$ Lysine, and $0.48 \%$ Methionine) and finisher (20\% CP, $3200 \mathrm{Kcal} / \mathrm{Kg} \mathrm{ME}, 0.90 \%$ Lysine, and $0.35 \%$ Methionine) diets. 
Three treatment diets for both starting and finishing periods were formulated as isocaloric isonitrogenous diets with $2 \%$ lower protein content than the control diet with addition of graded levels of L-lysine $\mathrm{HCl}$ and DL-methionine to give a proportions of $120 \%, 140 \%$, and $160 \%$ of the broiler's requirement (NRC, 2000) for Lysine and Methionine during the starting $(1.32,0.58 ; 1.54,68 ; 1.76,0.78 \%$ of both amino acids, respectively) and finishing $(1.08,0.42 ; 1.26,0.49 ; 1.44,0.56 \%$ of both amino acids, respectively) periods. The amino acids and nutrients contents of the rations were calculated according to their proportions in the used feed stuffs. The protein contents of the rations were checked out according to A. O. A. C. (1975) as shown in table (1).

Table (1): Experimental rations used during the starting and finishing periods.

\begin{tabular}{|c|c|c|c|c|c|c|c|c|}
\hline \multirow{2}{*}{ Ingredients } & \multicolumn{4}{|c|}{ Starter rations } & \multicolumn{4}{|c|}{ finisher rations } \\
\hline & $100 \%$ & $120 \%$ & $140 \%$ & $160 \%$ & $100 \%$ & $120 \%$ & $140 \%$ & $160 \%$ \\
\hline Ground corn & 49.5 & $\overline{59.2}$ & 59.0 & 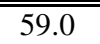 & 55.0 & 63.0 & 63.0 & 63.0 \\
\hline Soy bean meal & 37.5 & 31.5 & 31.4 & 31.18 & 32.0 & 26.5 & 26.5 & 26.4 \\
\hline Fish meal & 2.00 & 2.00 & 2.00 & 2.00 & 2.00 & 2.00 & 2.00 & 2.00 \\
\hline Soya oil & 7.40 & 3.60 & 3.60 & 3.50 & 8.20 & 5.50 & 5.30 & 5.00 \\
\hline Di-calcium Phosphate & 2.10 & 2.00 & 2.00 & 2.00 & 1.50 & 1.50 & 1.50 & 1.40 \\
\hline Lime stone & 0.70 & 0.60 & 0.50 & 0.50 & 0.50 & 0.50 & 0.40 & 0.40 \\
\hline Common salt & 0.40 & 0.40 & 0.40 & 0.40 & 0.40 & 0.40 & 0.39 & 0.40 \\
\hline Vitamins mix. ${ }^{1}$ & 0.25 & 0.25 & 0.25 & 0.25 & 0.25 & 0.25 & 0.25 & 0.25 \\
\hline Minerals mix. $^{2}$ & 0.15 & 0.15 & 0.15 & 0.15 & 0.15 & 0.15 & 0.15 & 0.15 \\
\hline L-lysine $\mathrm{HCl}$ & - & 0.24 & 0.45 & 0.67 & - & 0.18 & 0.36 & 0.54 \\
\hline DL-methionine & 0.15 & 0.24 & 0.25 & 0.35 & - & 0.07 & 0.15 & 0.25 \\
\hline \multicolumn{9}{|l|}{ Chemical composition: } \\
\hline Crude protein $\%$ & 22 & 20 & 20 & 20 & 20 & 18 & 18 & 18 \\
\hline ME Kcal/Kg & 3100 & 3000 & 3000 & 3000 & 3200 & 3050 & 3050 & 3050 \\
\hline Lysine\% & 1.10 & 1.32 & 1.54 & 1.76 & 0.90 & 1.10 & 126 & 1.44 \\
\hline Methionine $\%$ & 0.48 & 0.58 & 0.68 & 0.78 & 0.35 & 0.42 & 0.50 & 0.60 \\
\hline
\end{tabular}

${ }^{1}$ Vitamin Mixture: Provided the following per kilogram of diet, vitamin A (retinyl acetate) 8800 IU; Cholecalceferol $2200 \mathrm{IU}$; DL- $\alpha$-tocopheryl acetate, $11 \mathrm{IU}$; Menadion sodium bisulfite, $2.2 \mathrm{mg}$, Riboflavin $4.4 \mathrm{mg}$; D-calcium pantothenate, $8.8 \mathrm{mg}$; Nicotinic acid $44 \mathrm{mg}$; Pyridoxine hydrochloride, $2.2 \mathrm{mg}$; Folic acid, 0.55mg; D-biotine, $0.11 \mathrm{mg}$; Thiamine hydrochloride, $25 \mathrm{mg}$; Vitamin B12, 6.6 Yg; Choline, $220 \mathrm{mg}$; Ethoxyquine, $125 \mathrm{mg}$.

${ }^{2}$ Minerals mixture: provided the following per kilogram of diet; $\mathrm{Mn}, 60 \mathrm{mg}$; $\mathrm{Zn}, 50 \mathrm{mg}$; Fe, $30 \mathrm{mg}$; $\mathrm{Cu}$, $5 \mathrm{mg}$; I, $1.06 \mathrm{mg}$; Se, $0.1 \mathrm{mg}$. 
Feed intake, live body weight, body weight gain, and feed conversion were recorded weekly. At the end of the experimental period, three birds from each group were randomly chosen and weighed individually. Prior to slaughtering the birds, feed and water were withdrawn for 10 and 14 hr, respectively. They were slaughtered and processed to determine the dressing percentage and carcass characteristics.

Blood samples were drawn from the brachial veins of three chickens in each group at the end of the $5^{\text {th }}$ week of age, and sera were separated and stored at $-20 \mathrm{C}^{\circ}$. Sera were used to estimate serum levels $(\mathrm{mg} / \mathrm{dl})$ of Uric acid,Phosphorous, Calcium, and Creatinine according to the methods described elsewhere (Caraway, 1955; Goldenberg, 1966; Gindler, 1972; and Thomas, 1992, respectively). All measurable spectrophotometer's kits required for the estimation processes were obtained from Biomerieux (France)

\section{Statistical analysis:}

The collected data were analyzed by one way ANOVA using SPSS program, version $10\left(\right.$ SPSS $\left.^{\circledR}, \mathbf{1 9 9 9}\right)$.

\section{Results and Discussion}

As shown in table (2), the increased Lysine and Methionine content of the low-protein rations didn't affect body weights and body gains but increased the feed consumption and decreased the gain to feed ratio (feed conversion) of the birds during the starting period, which was in agreement with the finding of Rezaei et al. (2004) and Shutle et al., (1997) and wasn't in agreement with the finding of Sell (1993). 
Gaafar, Ket al.,

Table (2): Different growth performances during the starting period (Mean $\pm \mathrm{SE}$ ).

\begin{tabular}{|c|c|c|c|c|}
\hline \multirow{2}{*}{ Performances } & \multicolumn{4}{|c|}{ Experimental groups } \\
\hline & $100 \%$ & $120 \%$ & $140 \%$ & $160 \%$ \\
\hline Body weight (g) & $447 \pm 5.7^{\mathrm{a}}$ & $440 \pm 0.8^{\mathrm{a}}$ & $444 \pm 5.6^{\mathrm{a}}$ & $453 \pm 8.3^{\mathrm{a}}$ \\
\hline Body gain $\quad(g)$ & $404 \pm 5.7^{\mathrm{a}}$ & $397 \pm 8.0^{\mathrm{a}}$ & $401 \pm 5.6^{\mathrm{a}}$ & $410 \pm 8.3^{\mathrm{a}}$ \\
\hline Feed intake $(\mathrm{g})$ & 480 & 507 & 565 & 653 \\
\hline Feed conversion & $1.20 \pm 0.02^{\mathrm{c}}$ & $1.3 \pm 0.03^{\mathrm{d}}$ & $1.4 \pm 0.02^{b}$ & $1.6 \pm 0.03^{a}$ \\
\hline
\end{tabular}

a-b - Means within the same row having different superscript are significantly different $(\mathrm{P}<0.05)$.

As shown in table (3), during the finishing period, the body weights and gains were compensated with increased feed intake expressing them by increased feed conversion ratios for the birds fed on low-protein, Llysine and DL-methionine-supplemented diets compared with the control group. There were no significant differences in the body weight and gain between the groups supplemented with $140 \%$ and $160 \%$ of NRC requirement for both amino acids and in the feed conversion ratios between the groups supplemented with $120 \%$ and $140 \%$ of NRC requirement for both amino acids. The first low-protein, amino acidssupplemented diet (120\%) gave higher feed conversion, body weight, and gain than the control group. There were no significant differences in body weight gain and feed conversion between the $120 \%$ and $140 \%$ amino acids-supplemented diets in the low protein diets. The highest values for feed intake, body weight, and gain might be due to the high digestibility and availability of Methionine and Lysine. Similar results were obtained by Mokhtar et al., (2007) but were not in agreement with the finding of Sell (1993) who stated no effect on the body weight and feed conversion with supplementation of low-protein diets by L-lysine and DL-methionine. 
The interest is growing in studying the minimum dietary protein and amino acids levels to optimize poultry production and maximize the efficiency of protein use, therefore, the low-protein diet which contains $120 \%$ of NRC requirement for Lysine and Methionine is considered as the more economic diet compared with the other groups.

Table (3): Different growth performances during the growing period (Mean $\pm \mathrm{SE}$ ).

\begin{tabular}{||c||c|c|c|c||}
\hline \multirow{2}{*}{ Performances } & \multicolumn{4}{|c||}{ Experimental groups } \\
\cline { 2 - 5 } & $100 \%$ & $120 \%$ & $140 \%$ & $160 \%$ \\
\hline \hline Body weight (g) & $1585 \pm 14.7^{\mathrm{c}}$ & $1831 \pm 32^{\mathrm{b}}$ & $1939 \pm 32^{\mathrm{a}}$ & $1951 \pm 24^{\mathrm{a}}$ \\
Body gain (g) & $1542 \pm 15^{\mathrm{c}}$ & $1789 \pm 32^{\mathrm{b}}$ & $1841 \pm 23^{\mathrm{ab}}$ & $1898 \pm 24^{\mathrm{a}}$ \\
Feed intake (g) & 2970 & 3027 & 3230 & 3523 \\
Feed conversion & $1.93 \pm 0.023^{\mathrm{b}}$ & $1.71 \pm 0.031^{\mathrm{c}}$ & $1.75 \pm 0.026^{\mathrm{c}}$ & $1.86 \pm 0.023^{\mathrm{a}}$ \\
\hline
\end{tabular}

${ }^{\mathrm{a}-\mathrm{b}}$ - Means within the same row having different superscript are significantly different $(\mathrm{P}<0.05)$.

Table (4) shows that, carcass, abdominal fat, and thigh meat yield were not affected by feeding low-protein diets those supplemented with L-lysine and DL-methionine but the breast meat yield increased with feeding of diet contained the highest levels of Lysine and Methionine (160\% of NRC requirement). These results were similar to those of Mokhtar et al., (2007) and Waldroup et al., (1997) but were not in agreement with the finding of Sell et al., (1994) who find that, a reduction or no effect on breast meat yield occurred by reducing $\mathrm{CP}$ content of the diets-supplemented with L-lysine and DL-methionine. It could be concluded that the supplementation of low-protein diet with a minimal level of amino acids (120\%) produced high feed conversion but was inadequate for production of high carcass yield. 
Gaafar, Ket al.,

Table (4): Carcass quality of the birds in the experimental groups (Mean $\pm \mathrm{SE}$ ).

\begin{tabular}{|c|c|c|c|c|}
\hline \multirow{2}{*}{ Performances } & \multicolumn{4}{|c|}{ Experimental groups } \\
\hline & $100 \%$ & $120 \%$ & $140 \%$ & $160 \%$ \\
\hline Carcass $^{1} \quad \%$ & $70.5 \pm 0.7^{\mathrm{a}}$ & $69.4 \pm 0.7^{\mathrm{a}}$ & $71.6 \pm 1.6^{\mathrm{a}}$ & $70.4 \pm 0.8^{\mathrm{a}}$ \\
\hline Abdominal fat ${ }^{2} \%$ & $1.82 \pm 0.09^{\mathrm{a}}$ & $1.60 \pm 0.06^{\mathrm{a}}$ & $1.84 \pm 0.09^{\mathrm{a}}$ & $1.83 \pm 0.02^{\mathrm{a}}$ \\
\hline Breast meat ${ }^{2} \%$ & $23.8 \pm 0.47^{\mathrm{c}}$ & $25.7 \pm 0.44^{\mathrm{b}}$ & $28.6 \pm 0.65^{\mathrm{a}}$ & $29.7 \pm 0.23^{\mathrm{a}}$ \\
\hline Thigh meat $^{2} \quad \%$ & $16.4 \pm 0.80^{\mathrm{a}}$ & $17.4 \pm 1.30^{\mathrm{a}}$ & $16.7 \pm 0.60^{\mathrm{a}}$ & $17.9 \pm 0.30^{\mathrm{a}}$ \\
\hline
\end{tabular}

a-b - Means within the same row having different superscript are significantly different $(\mathrm{P}<0.05)$.

1 Percentage of body weight.

${ }^{2}$ Percentage of carcass weight.

Table (5) shows that feeding of broilers on low-protein diet reduced significantly the level of Uric acid in the plasma as compared with the control group. However, the high levels of synthetic amino acids supplementation decrease the concentrations of Uric acid in the plasma compared with the low level of amino acids as indicator for the increased nitrogen excretion. The high Uric acid content of plasma with feeding high-protein diet (control) and low protein diet that supplemented with the highest level of amino acids (160\%) might be due to the negative effect on the tissue metabolism (Namroud et al., 2008). These investigations were recorded with most of studies of feeding birds on low protein diets(Roberts et al.,2007, Keshavarz and Austic 2004).Plasma Creatinine level increased significantly with the highest levels of synthetic amino acid supplementation compared with the low supplementation levels and the control group, which might be attributed to the increased levels of Methionine as Methyl donors. This was in agreement with the finding of Chamruspollert et al.,(2002), and wasn't agreed with that of Wilburn and Fuller (1975). 
Effect Of Feeding Low-Protein, L-Lysine And Dl-Methionine-...

Table (5): Different blood parameters of the experimental groups (Mean \pm SE).

\begin{tabular}{||c||c|c|c|c||}
\hline \multirow{2}{*}{ Performances } & \multicolumn{4}{|c||}{ Experimental groups } \\
\cline { 2 - 5 } & $\mathbf{1 0 0 \%}$ & $\mathbf{1 2 0 \%}$ & $\mathbf{1 4 0 \%}$ & $\mathbf{1 6 0 \%}$ \\
\hline \hline Uric acid mg/dl & $5.50^{\mathrm{a}}$ & $4.10^{\mathrm{c}}$ & $4.80^{\mathrm{b}}$ & $4.90^{\mathrm{b}}$ \\
\hline Creatinine $\mathrm{mg} / \mathrm{dl}$ & $0.44^{\mathrm{b}}$ & $0.43^{\mathrm{b}}$ & $0.44^{\mathrm{b}}$ & $0.51^{\mathrm{a}}$ \\
\hline Calcium $\mathrm{mg} / \mathrm{dl}$ & $7.80^{\mathrm{a}}$ & $8.04^{\mathrm{a}}$ & $9.00^{\mathrm{a}}$ & $9.30^{\mathrm{a}}$ \\
\hline Phosphorus $\mathrm{mg} / \mathrm{dl}$ & $5.40^{\mathrm{a}}$ & $6.00^{\mathrm{b}}$ & $6.20^{\mathrm{b}}$ & $6.80^{\mathrm{c}}$ \\
\hline
\end{tabular}

a-b- Means within the same row having different superscript are significantly different $(P<0.05)$.

As shown in table (5), Plasma levels of Calcium were not affected by either protein reduction or synthetic amino acids supplementation of the diets but those of Phosphorus were significant increased with the levels of synthetic amino acids supplementation of the diets. The plasma Phosphorus concentration was considered as indirect indicator for thyroid (Sethi et al., 2008) and growth hormones (Carew et al., 1985) status in the body. The increased levels of plasma Phosphorus might be indirect indicators for the growth initiative effect of the used synthetic amino acids in the three experimental groups compared with the control group, which needs more investigations in the future.

\section{CONCLUSION}

It is possible to ensure the same productivity with financial benefits by feeding out feed with decreasing its protein content and corresponding utilizable Lysine and Methionine supplementation as with optimum protein content in feed. The minimum levels of protein $(20 \%$ and $18 \%$ $\mathrm{CP} \%$ for starting and finishing periods, respectively) in the diets supplemented with Methionine, and Lysine (120\% of requirement) for broilers ensure an optimum body weight, body gain, and food conversion 
with reduced Nitrogen excretion but were inadequate to produce the highest breast meat yield. Abdominal fat and thigh meat yield weren't affected neither by reducing the dietary protein nor supplementation of the diets by synthetic amino acids. The reduced Nitrogen excretion of birds fed on low-protein diets has an important environmental concern in the poultry houses. It was apparent that amino acids could be effective to replace a portion of concentrates, which is the more expensive part of the broiler's diets.

\section{REFERENCES}

- A. O. A.C.(1975) : Official methods of analysis (12 ${ }^{\text {th }}$ ed.) Association of Official Analytical Chemist. Washington, D. C.

- Aletor, V. A., Hamid, I. I.,Neib, E and Pfeffer, E. (2000): Low protein amino acid supplemented diets in broiler chickens: effects on performance, carcass characteristics, whole body composition and efficiency of nutrient utilization. Journal of Science, Food and Agriculture, 80: 547-554.

- Alleman, F. and B. Leclercq, (1997): Effect of dietary protein and environmental temperature on growth performance and water consumption of male broiler chickens. Britissh Poultry Science, 38: $607-610$.

- Caraway, W., (1955): Determination of uric acid in serum and urine. Am. J. Clin. Path., 25: 840.

- Carew LB Jr, Gestone TA, Alster FA, Scanes CG, (1985): Effect of phosphorus deficiency on thyroid function and growth hormone in the white Leghorn male. Poultry Science. 1985;64(10):2010-2.Links. 
- Chamruspollert,M., G.M.Pesti, and R.I.Bakalli,(2002): The influence of labile dietary Methyl Donors on the Arginine requiremwnt of young Broiler chicks. Poultry Science 2002, 81: 1142- 1148.

- Gindler,E.,(1972): Colorimetric determination of serum calcium. Am. J. Clin. Path., 58: 367.

- Goldenberg, H., (1966): Determination of inorganic phosphorus. Clin. Chem., 12: 871.

- Hickling, D. R., Guenter, W., and Jackson, M. E., (1990): The effect of dietary methionine and Lysine on broiler chicken performance and breast meat yield. Can. J. Anim. Sci., 70: 763-768.

- Hueghebaert, G., Pack, M., and De Groote, G. (1994): Influence of protein concentration on the response of broilers to supplemental DLmethionine. Archive Fur Geflugelkunde, 58: 23-29.

- Jackson, M. R.., Li, S., Day, E. J., and Omar, S., (1989): The effect of different Lysine level fed in constant proportion to different crude protein level on the live performance and carcass characteristics of broiler chicken. Poultry Science, 68 (Supplement): 186 (Abstract).

- Keshavarz, K. and R. E. Austic, (2004): The use of low-protein, low phosphorus, Amino acids- and Phytase-supplemented diets on laying hen performance and Nitrogen and Phosphorus excretion. Poultry Science 2004. 83: 75- 83.

- Mokhtar Ahmad Mokhtar,A., Mekkawi,A., and El Tigani, M. (2007): The effect of feeding increasing levels of synthetic Lysine and Methionine in broiler chicks. Research Journal of Animal and Veterinary Science, 2: 18-20. 
- Namroud, F. N., Shivazad, M., and M. Zaghari, (2008): Effects of Fortifying Low Crude Protein Diet with Crystalline Amino Acids on Performance, Blood Ammonia Level, and Excreta Characteristics of Broiler Chicks. Poultry Science 2008: 87: 2250-2258.

- NRC, (2000): National Research Council of United state of America.

- Ohta, Y.and Ishibashi,T.(1995): Effects of dietary glycine on reduced performance by deficient and excessive methionine in broilers. Japanese Poultry Science. 31: 81-89

- Rezaei M., Nassiri Moghaddam H., Pour Reza J., and Kermanshahi H. (2004): The effect of dietary protein and Lysine levels on broiler performance, carcass characteristics and $\mathrm{N}$ excretion. International Journal of poultry Science, 3 (2): 148-152.

- Roberts, S. A., H. Xin, B. J. Kerr, J. R. Russell and K. Bergendahl, (2007): Effects of dietary fibre and reduced crude protein on Nitrogen balance and Egg production in laying hen. Poultry Science, 2007: 86: $1716-1725$.

- Schutle, J. B., De Jong, J., Smink, W., and M. Pack, (1997): Replacement value of Betaine for DL-methionine in male broiler chicks. Poultry Science, 76: 321-325.

- Sell,J.L., (1993): Influence of metabolizable energy feeding sequence and dietary protein on performance and selected carcass traits of tom turkeys. Poultry Science, 72: 521-534

- Sell, J. L., Jeffrey, M. J., and Kerr, B. J. (1994): Influence of amino acid supplementation of low protein diets and metabolizable energy feeding sequence of performance and carcass composition of toms. Poultry Science, 73: 1867-1880. 
- Sethi, P., G. Pesti, S. Aggrey, (2008): Physiological responses of divegent selection for phytate Phosphorus Bioavailability in a randombred chicken population. Poultry Science, 2008, 87: 25122516.

- Simone, A., Bergner, H. and Buivan, D. (1995): Methodological investigation on the metabolism oriented determination of methionine requirement of broiler chickens. 3. Degradation of $14 \mathrm{C}-(\mathrm{CH} 3)-$ and 35-S- methionine after feeding of synthetic diets. Archive in Animal Nutrition. 47: 229-244

- SPSS®, (1999): Computer software 10.00, SPSS Inc., Head-quarters. Wacker Drive, Chicago, 1llinois 60606, USA.

- Thomas, C., (1992): Labor und diagnose. Medizininche Verlagsgesellschaft, Marburg.

- Waldroup,P.W.,Adams,H.M., and Waldroup,L.A.,(1997): Evaluation of National Research Council Amino acid Recommendations for Large White Turkeys. Poultry Science, 76: 711-720

- Wilburn,D.R., and H. L. Fuller. (1975): The effect of methionine and lysine levels on the arginine requirement of the chick. Poultry Science, $54: 248-256$.

- Yamazaki, M., Murakami, H. and Takemasa, M. (1998): Effects of ratios of essential amino acids to non-essential amino acids in low protein diet on excretion and fat deposition of broiler chicks. Japanese Poultry Science. 35: 19-26. 
Gaafar, K et al.,

\section{تأثير تغذية علائق منخفضة المحتوى من البروتين والمضاف إليها الليسين والميثيونين

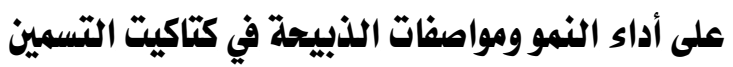

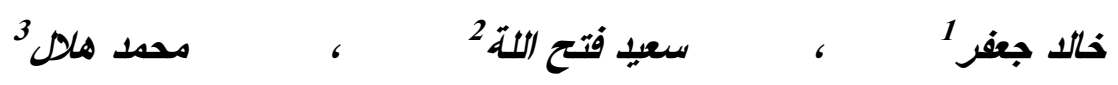

1 قسم التفذية والتغذية الإكلينيكية ، كلية الطب البيطري بالسادات،جامعة المنوفية

قسم الفسيولوجيا، كلية الطب البيطري بالسادات،جامعة المنوفية

3 قسم الرعاية وتنمية الثروة الحيو انية، كلية الطب البيطري بالسادات،جامعة المنوفية

أجريت هذه الدراسة على عدد 200 كتكوت تسمين غير مجنس عمر يوم حيث تم تقسيمهم إلى تص

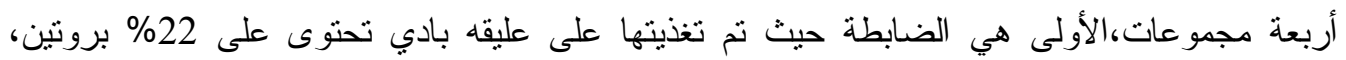

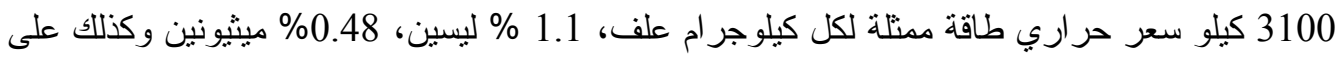

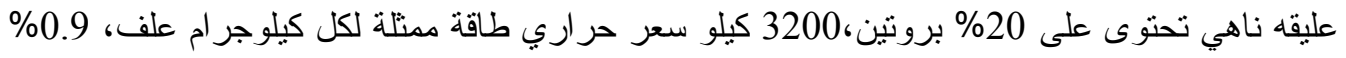
ليسين، 0.35\% ميثيونين.

وتم تغذية، الثلاث مجموعات الأخرى على ثناث علثن علائق بادي وناهي منساوية المحتوى من الطاقة و البروتين ولكن تحتوين على 2\% أقل من البروتين من المجموعة الضابطة في فترتي البادي

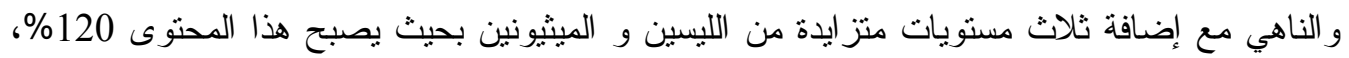
140، 160\% من الاحتياج الطبيعي للمجموعة الضابطة.

\section{واقد لوهظ من النـنائج ما بلئي:}

1- في نهاية فترة الباديئ لم نتأثر أوزان الطيور ومعدلات الزيادة في الأوزان مع زيادة في معدلات التحويل الغذائي واستهلاك العلف التي تم تغذيتها على علائق منخفضة المحتوى من البرونين مع إضافة الليسين و الميثيونين إليهن.

2- في نهاية التجربة كان هناك زيادة فى أوزان الطيور و الزيادة الوزنية و استهلاك العلف ووزن لحون الحوم

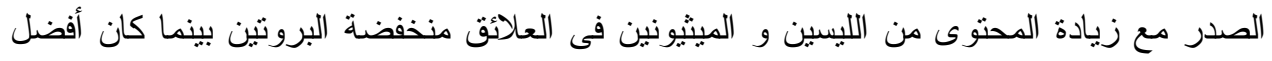
معدل تحويل غذائي فى الطيور اللائى تم تغذيتهن على علائق منخفضة البروتين وتحتوى على 120

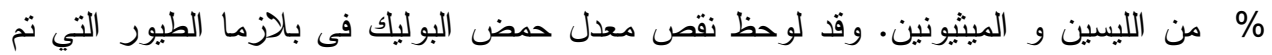
تغذيتهن على علائق منخفضة المحتوى من البروتين مع زيادة محتو اهن من الليسين و الميثيونين.

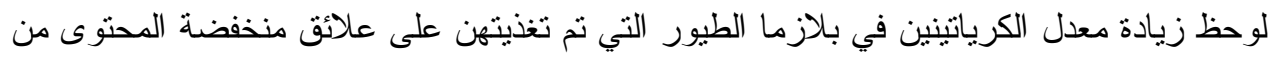

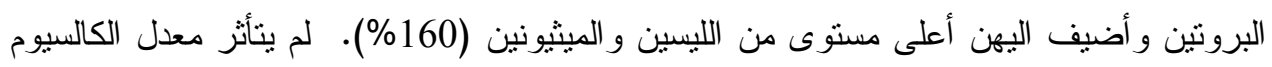
في بلازمة الطيور مع كل المعاملات و لكن محتواهن من الفسفور تزايد في الطيور التي تم تغذيتهن على علائق منخفضة المحتوى من البروتين مع زيادة النسب المضافة من الليسين و الميثيونين إلى هذه العلائق و التي من الممكن أن تكون دليلا على تحفيز النمو فيهن. 